\title{
SEED MORPHOLOGY AND CLASSIFICATION OF IMPATIENS (BALSAMINACEAE)
}

\author{
NANDA UTAMI ${ }^{1} \&$ TATEMI SHIMIZU ${ }^{2}$
}

\begin{abstract}
SUMMARY
Seed coat morphology was observed through SEM for 65 species and 10 sections of Impatiens. Several types of seed coat are recognized in this study. On the basis of comparison with other characters such as chromosome numbers, floral characters and seedling morphology, systematic problems concerning Impatiens are briefly discussed.
\end{abstract}

Key words: Balsaminaceae, Impatiens, seed coat, classification.

\section{INTRODUCTION}

The Balsaminaceae, a family consisting mostly of subsucculent annual or perennial herbs, is usually regarded as comprising two genera, the monotypic Hydrocera Blume ex Wight \& Arn. and the prolific Impatiens L. with an estimated number of about 850 species (Grey-Wilson, 1980). The genus Impatiens is concentrated in mountainous regions of South-East Asia, South China, India and Africa. Like most genera of comparable or larger size Impatiens suffers from a rather confused taxonomy and the absence of recent comprehensive revisions.

Studies on seed coat morphology have been carried out by several researchers. Wunderlich (1967), Corner (1976) and Kumar \& Singh (1990) pointed out the significance of seed coat morphology in solving problems of classification and in phylogenetic considerations. The seed coat ornamentation in the genus Impatiens has been given attention since Hooker \& Thomson (1859), but without comprehensive surveys. In the following account the seeds of 65 species and 10 sections of Impatiens in the sense of Warburg \& Reiche (1895) are described and the contribution that seed coat may make to the taxonomy of the family is considered.

\section{MATERIALS AND METHODS}

Seed samples of 65 species of Impatiens representing two subgenera, 10 sections (2 sections of subg. Acaulimpatiens and 8 sections of subg. Impatiens) taken from the field or herbarium specimens in Kanazawa University (KANA), Japan and the Herbarium Bogoriense, Bogor Indonesia (BO) (See Table 1). The samples were air dried, mounted, coated with gold and observed with SEM (AKASHI ALPHA) 30A at $15 \mathrm{kV}$ and magnification 30-300.

1) Herbarium Bogoriense, Botany Division, Research Centre for Biology-LIPI, Jalan Ir. Juanda 22, Bogor 16122, Indonesia.

2) Shimizu Botanical Laboratory, 211-3 Okada-matsuoka, Matsumoto 390-3, Japan. 
Table 1. Impatiens species examined.

\begin{tabular}{|c|c|c|c|c|}
\hline Subgenus & Section & Species & Locality & Voucher \\
\hline \multirow{4}{*}{$\begin{array}{l}\text { Acaulimpatiens } \\
\text { Warb. }\end{array}$} & \multirow[t]{2}{*}{ Scapimpatiens Warb. } & I. acaulis Arn. & India: W Ghats & KANA 190708 \\
\hline & & I. scapiflora Heyne & India: W Ghats & KANA 192267 \\
\hline & \multirow[t]{2}{*}{ Orchimpatiens Warb. } & I. modesta Wight. & India: W Ghats & KANA 192266 \\
\hline & & $\begin{array}{l}\text { I. stocksii } \\
\text { Hook.f. \& Thomson }\end{array}$ & India: W Ghats & KANA 192257 \\
\hline \multirow[t]{41}{*}{ Impatiens Warb. } & \multirow[t]{10}{*}{ Enantiophyllon Warb. } & I. chinensis L. & Thailand: Loei & KANA 190740 \\
\hline & & I. helferi Hook.f. & China & BR (Perrotet 188) \\
\hline & & I. kleinii Wight. \& Arn. & India: W Ghats & KANA 194742 \\
\hline & & I. masoni Hook.f. & Thailand: Petchaburi & KANA 189638 \\
\hline & & I. proctrata Hook.f. & Indochina & $\mathrm{P}$ (type) \\
\hline & & I. gardneriana Wight. & India: W Ghats & KANA 194740 \\
\hline & & $\begin{array}{l}\text { I. griffithii } \\
\text { Hook.f. \& Thomson }\end{array}$ & Malaya: Pahang & KANA 190762 \\
\hline & & I. javensis Steud & Indonesia: W Java & KANA 189552 \\
\hline & & I. platypetala $\mathrm{L}$. & Indonesia: W Java & BO 114839 \\
\hline & & I. relaxata Hook.f. & Indochina & $\mathrm{P}$ (isotype) \\
\hline & \multirow[t]{15}{*}{ Macrocentron Warb. } & $\begin{array}{l}\text { I. chiangdaoensis } \\
\text { T. Shimizu }\end{array}$ & \multicolumn{2}{|c|}{ Thailand: Chiang Mai KANA 190274} \\
\hline & & I. diffusa Hook.f. & Indochina & KANA 194790 \\
\hline & & I. longicalcarata Tardieu & Indochina & $\mathrm{P}$ (type) \\
\hline & & I. monotrica Hook.f. & Indochina & P (type) \\
\hline & & I. noei Craib & Thailand: Huiyang & KANA 189850 \\
\hline & & I. obscura Hook.f. & Indochina & P (type) \\
\hline & & I. patula Craib & Thailand: Chiang Mai & KANA 189742 \\
\hline & & I. rara Tardieu & Indochina & P (type) \\
\hline & & I. santisukii T. Shimizu & Thailand: Chiang Mai & KANA 189885 \\
\hline & & I. subaequalis Craib & $\begin{array}{l}\text { Thailand: Prachuap } \\
\text { Khiri Khan }\end{array}$ & KANA 189917 \\
\hline & & I. thorelii Hook.f. & Indochina & P (THOREL 2112) \\
\hline & & I. violiflora Hook.f. & Thailand: N. Tak & KANA 189932 \\
\hline & & I. henslowiana Arn. & Indochina & KANA 194740 \\
\hline & & I. muscicola Craib & Thailand & KANA 189679 \\
\hline & & I. siamensis T. Shimizu & Thailand & KANA 189892 \\
\hline & \multirow[t]{16}{*}{ Microcentron Warb. } & I. balsamina $\mathrm{L}$. & $\begin{array}{l}\text { India, Burma, } \\
\text { Indonesia }\end{array}$ & 0 \\
\hline & & I. bunnackii T. Shimizu & Thailand & KANA 198551 \\
\hline & & I. charanii T. Shimizu & Thailand & KANA 189567 \\
\hline & & I. harmandii $\mathrm{T}$. Shimizu & Thailand & P (HARMAND 187) \\
\hline & & I. kanburiensis T. Shimizu & Thailand & KANA 189593 \\
\hline & & I. macrosepala Hook.f. & Thailand & KANA 189850 \\
\hline & & I. obesa Hook.f. & China: Kwantung & $\mathrm{PE}$ \\
\hline & & I. saraburiensis T. Shimizu & Thailand: Saraburi & KANA189903 \\
\hline & & I. hongsonensis T. Shimizu & Thailand: Maehonson & KANA 189546 \\
\hline & & I. kerriae Craib & Thailand: Chiang Mai l & KANA 189623 \\
\hline & & I. psittacina Hook.f. & Thailand: Chiang Mai & KANA189805 \\
\hline & & I. verucifer Hook.f. & Indochina & P (Balansa 113) \\
\hline & & I. boni Hook.f. & Indochina & $\mathrm{P}$ \\
\hline & & I. namkatensis T. Shimizu & Thailand: Maehonson & KANA 190046 \\
\hline & & I. capusii Hook.f. & Indochina & P (type) \\
\hline & & I. glandulifera Royle & UK: Surrey & KANA 189543 \\
\hline
\end{tabular}


Table 1 (cont.)

\begin{tabular}{|c|c|c|c|c|}
\hline Subgenus & Section & Species & Locality & Voucher \\
\hline & Megalocentron Warb. & I. garrettii Craib & \multirow{2}{*}{\multicolumn{2}{|c|}{$\begin{array}{l}\text { Thailand: Chiang Mai KANA } 189548 \\
\text { Indonesia: W Sumatra KANA } 189424\end{array}$}} \\
\hline & & $\begin{array}{l}\text { I. tapanuliensis } \\
\text { Grey-Wilson }\end{array}$ & & \\
\hline & & $\begin{array}{l}\text { I. diepenhorstii } \\
\text { Grey-Wilson }\end{array}$ & \multicolumn{2}{|c|}{ Indonesia: W Sumatra KANA189347 } \\
\hline & & I. oncidioides Ridl. & Malaya & KANA 187115 \\
\hline & & I. dewildeana Grey-Wilson & Indonesia & BO 115674 \\
\hline & & I. mengtzeana Hook.f. & \multirow{2}{*}{\multicolumn{2}{|c|}{$\begin{array}{l}\text { South China, ThailandKANA } 189620 \\
\text { Indonesia: W Sumatra KANA } 189367\end{array}$}} \\
\hline & & $\begin{array}{l}\text { I. pseudoperezii } \\
\text { Grey-Wilson }\end{array}$ & & \\
\hline & & $\begin{array}{l}\text { I. sidikalangensis } \\
\text { Grey-Wilson }\end{array}$ & \multicolumn{2}{|c|}{ Indonesia: W Sumatra KANA 189396} \\
\hline & & I. vittelina Grey-Wilson & \multicolumn{2}{|c|}{ Indonesia: W Sumatra KANA 189399} \\
\hline & Brachycentron Warb. & I. hypophylla Makino & Japan: Kyushu & KANA 153136 \\
\hline & & I. textori Miq. & Japan: Ishikawa & KANA 109208 \\
\hline & & I. noli-tangere $\mathrm{L}$. & Japan: Nagano & KANA 182684 \\
\hline & & I. alboflava Miq. & \multicolumn{2}{|c|}{ Indonesia: W Sumatra KANA 189413} \\
\hline & & I. larsenii $\mathrm{T}$. Shimizu & Thailand: Surathani & KANA 189594 \\
\hline & Longicornes Warb. & I. cordata Wight & India: W Ghats & KANA 194866 \\
\hline & & I. walleriana Hook.f. & Cultivated & NONE \\
\hline & Salpingochillon Warb. & I. benthami Steenis & India & KANA 196463 \\
\hline & & I. goughii Wight & India: W Ghats & KANA 194874 \\
\hline & Choniochillon Warb. & I. omissa Hook.f. & India: W Ghats & KANA 196466 \\
\hline & & I. viscosa Bedd. & India: W Ghats & KANA 194922 \\
\hline
\end{tabular}

\section{RESULTS AND DISCUSSIONS}

The Balsaminaceae have small- to medium-sized seeds, that are exarillate, exalbuminous and in most cases pachychalazal, the integument is not or scarcely multiplicative. The seed coat is formed by the expanded chalaza; the testa (outer or exotesta) is unspecialized or the cells have a papilla or a hair; the mesophyll is unspecialized, more or less crushed; the tegmen when present becomes crushed. The vascular bundle ends at the chalaza. The endosperm is cellular but absorbed. The embryo is straight (Corner, 1976). Parenchyma, tannin, crystal, mucilage, cork and sclerenchyma or collenchyma cells all contribute to the differentiation and build-up of the seed coat. The seed coat of Balsaminaceae usually contains crystals. However, the function of the crystals in the seed coat is unknown. They may serve as storage organs of waste products, defence against animal predators or, especially in the case of silicate crystals, assist in mechanical protection (Boesewinkel \& Bouman, 1984).

In the last decade the SEM technique has opened an entire new field of micromorphological research on seed coats. Brisson \& Peterson (1976) reviewed the use of SEM in the study of seed coats. They found that several features can be distinguished on the surface of the seed by SEM. Our study focuses on seed morphology of the genus Impatiens. The descriptions of the seed coats follow Grey-Wilson's (1980) and Barthlott's (1990) terminology. Scanning Electron Micrographs (SEM) of the representative seed coat types of Impatiens species examined are presented in Plate 1-4. 


\section{A. Subgenus Acaulimpatiens Warb.}

From Plate $1 \mathrm{a} \& \mathrm{~b}$ (I. acaulis Arn., I. stocksii Hook.f. \& Thomson) it can be seen that subg. Acaulimpatiens has two types of seed coat. The seeds of I. acaulis (Plate 1a) are covered with broad and ring patterned hairs of 40-50 $\mu \mathrm{m}$ diam., while those of I. stocksii (Plate $1 \mathrm{~b}$ ) have long and slender hairs of 30-37 $\mu \mathrm{m}$ diam. at both ends only. This indicates that the subgenus may be divided at least into two sections, supporting
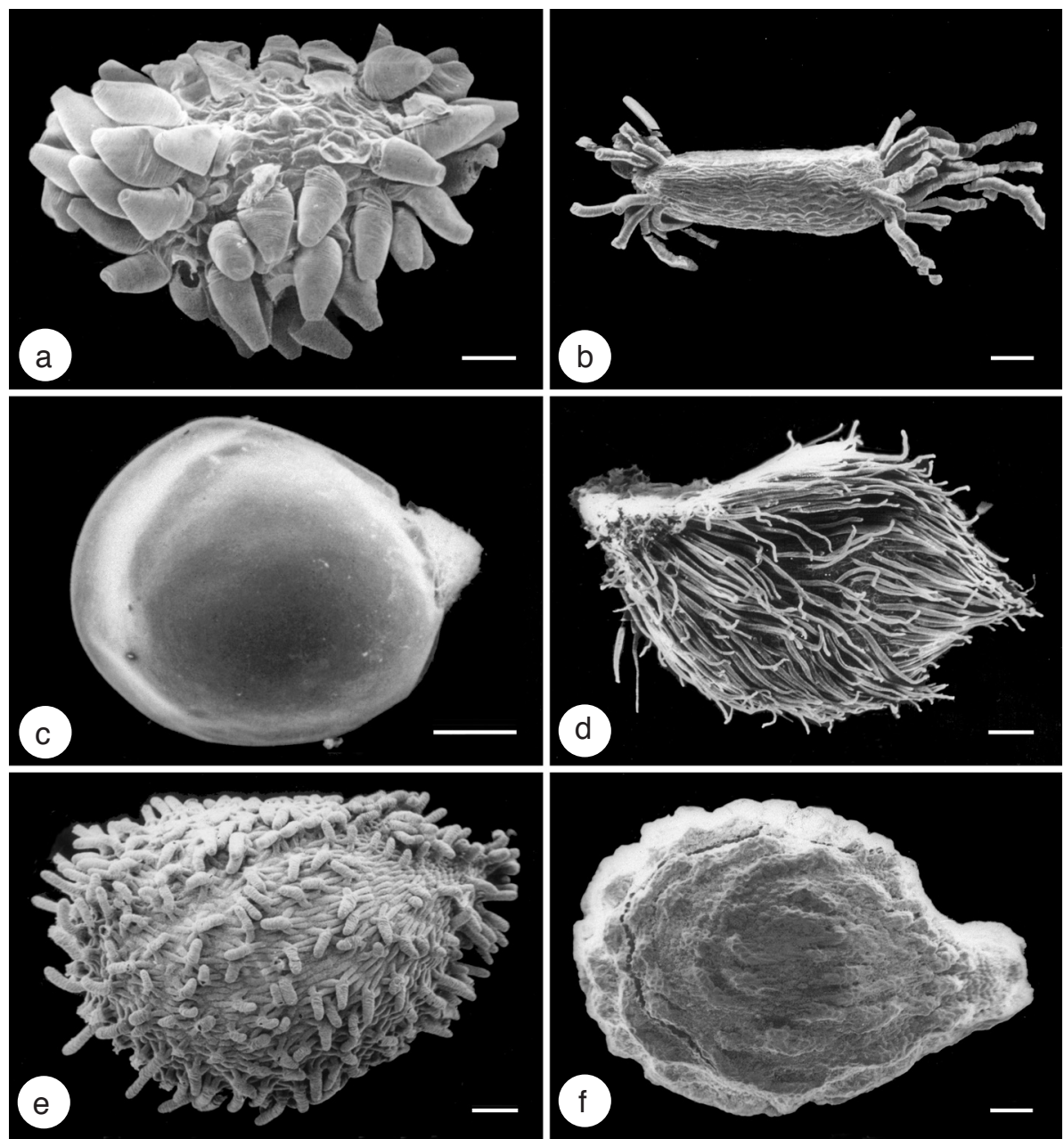

Plate 1. SEM-photographs of seeds of Impatiens species. - a \& b: Subg. Acaulimpatiens Warb.: a. Sect. Scapimpatiens Warb.: I. acaulis Arn. with short and thick hairs on the surface; b. Sect. Orchimpatiens Warb.: I. stocksii Hook.f. \& Thomson with long and slender hairs on the surface, only at both ends. - c-f: Subg. Impatiens: c \& d. Sect. Enantiophyllon Warb.: c. I. chinensis L. with smooth seeds; d. I. gardneriana Wight with long hairs around the testa; e \& f. Sect. Macrocentron Warb.: e. I. patula Craib: testa with tufts of helical 'hairs'; f. I. henslowiana Arn.: testa irregular with isodiametric cells with reticulate thickened outer walls. - Scale bars: $\mathrm{a}=100 \mu \mathrm{m} ; \mathrm{b}=175 \mu \mathrm{m} ; \mathrm{c} \& \mathrm{e}=$ $330 \mu \mathrm{m} ; \mathrm{d}=250 \mu \mathrm{m} ; \mathrm{f}=320 \mu \mathrm{m}$. 
the classification of Warburg \& Reiche (1895) who divided subg. Acaulimpatiens into two sections on the basis of floral shape: sect. Scapimpatiens Warb. with big, longspurred flowers and sect. Orchimpatiens Warb. with small, short-spurred flowers. The two sections also show differences in chromosome numbers. In I. scapiflora F. Heyne of sect. Scapimpatiens $2 \mathrm{n}=6,8,10,16$ and 20 have been counted, while in I. stocksii of sect. Orchimpatiens the chromosome number is n = 7 and 10 (Bhaskar \& Razi, 1972). Shimizu et al. (1990) reported two anther types in this subgenus: tetrasporangiate (I. acaulis and I. scapiflora) and trisporangiate (I. modesta Wight and I. stocksii). The species I. acaulis and I. scapiflora have a seedling morphology of the 'third type' (Shimizu, 1982). Together seed coat morphology, seedlings, anther type and chromosome numbers support the classification given by Warburg \& Reiche (1895).

\section{B. Subgenus Impatiens Warb.}

The most interesting problems are to be found in subg. Impatiens in which the species show considerable diversity in their seed coat pattern. Eight sections were examined in this study. They are as follows:

\section{Section Enantiophyllon Warb.}

This section is variable in seed coat patterns, which can be divided into two groups as shown in Plate 1c-f (I. chinensis L., I. gardneriana Wight, I. patula Craib, I. henslowiana Arn.). Group I is characterized by black globose seeds with a glabrous and shining surface as found in I. chinensis (Plate 1c), I. kleinii Wight \& Arn., I. masoni Hook.f. and I. proctrata Hook.f. All species of this group share opposite or whorled leaves, but differ in seedling morphology. The seedling morphology of I. chinensis belongs to 'subgroup F', while I. masoni is assigned to 'subgroup H' (Shimizu, 1982). The chromosome number of I. chinensis and I. kleinii is $2 \mathrm{n}=16$ (Shimizu, unpubl.; Zinov'Eva-Stahevitch, 1981). Group II: Seeds densely covered with long hairs on the surface, whorled leaves and seedling morphology 'subgroup E' (Shimizu, 1982). The chromosome number of I. gardneriana (Plate 1d) and I. platypetala L. is $2 \mathrm{n}=$ 16 (Bhaskar \& Razi, 1974; Zinov'Eva-Stahevitch, 1981). Bhaskar \& Razi (1978) divided sect. Enantiophyllon into two subsections on the basis of phyllotaxis, subsect. Oppositifoliae Bhaskar \& Razi, including all of the members of Group I and subsect. Verticillatae Bhaskar \& Razi which refers to Group II. As a result, his subdivision is well concordant with the present grouping, although it is not always supported by seedling type and chromosome number.

\section{Section Macrocentron Warb.}

This section is characterized by alternate leaves and only one or two flowers with long spurred lips per inflorescence. The seed coat morphology suggests division of the species examined into three groups. Group I has a testa with tufts of helical 'hairs' (Plate 1e, I. patula) and is further characterized by pink flowers, turgid and tomentose capsules and seedling type 'subgroup C' (Shimizu, 1982). Their distribution is strictly restricted to South-East Asia. This is a natural group to be treated as an independent taxon. Impatiens henslowiana of Group II (Plate 1f) is characterized by an irregular 

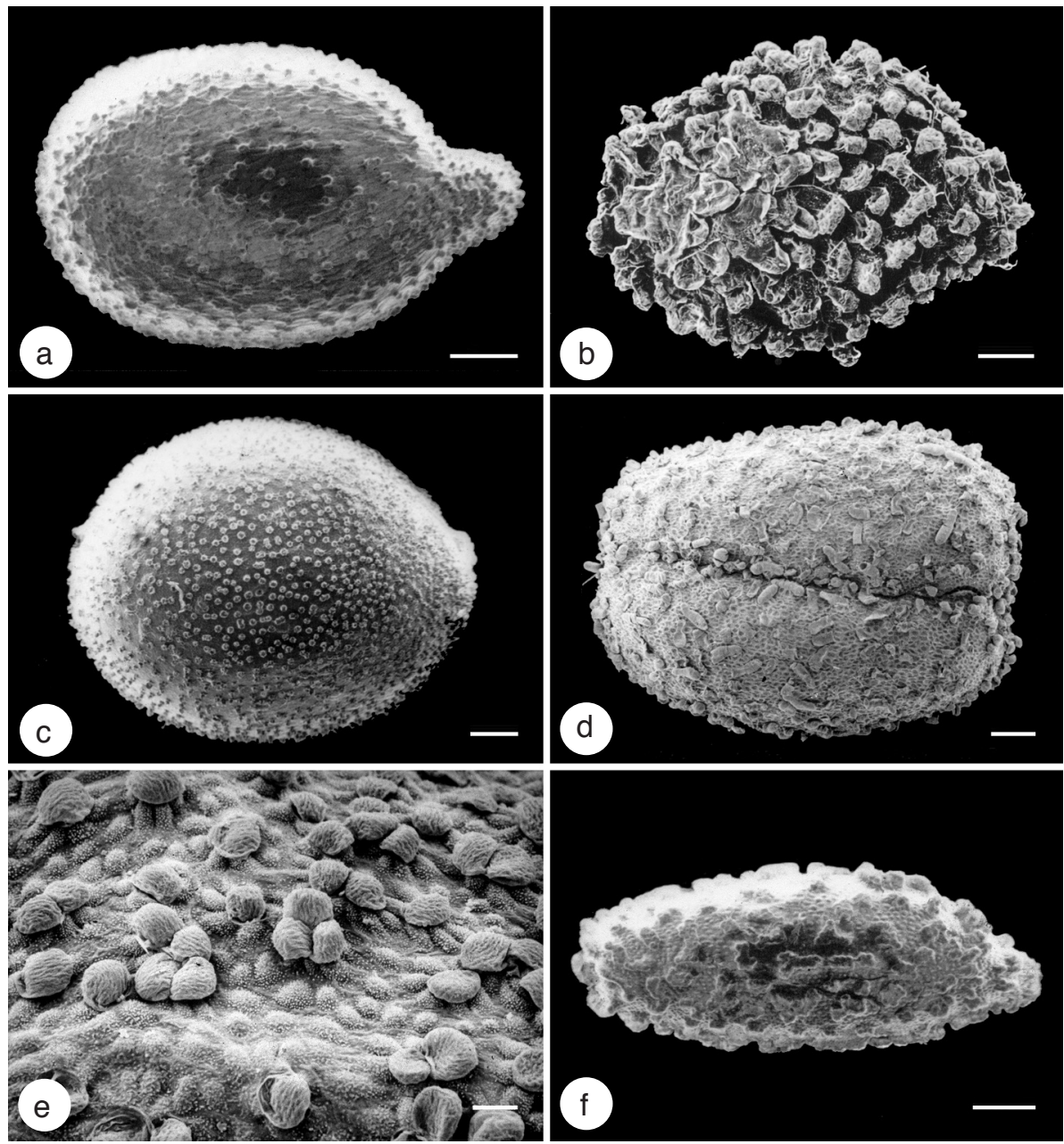

Plate 2. SEM-photographs of seeds of Impatiens species. - a \& b: Sect. Macrocentron Warb.: a. I. muscicola Craib with short 'hair-like' protuberances; b. I. siamensis T. Shimizu with a 'warted' epidermis. - c-f: Sect. Microcentron Warb.: c. I. balsamina L.: testa covered with small peculiar wart-like outgrowths; d. I. harmandii Hook.f.: testa cells with reticulate thickened outer walls and long, helical 'hair-like' structures; e. I. psittacina Hook.f.: outer walls of the testa cells are granulate; f. I. namkatensis T. Shimizu: testa cells with bulging outer walls. - Scale bars: a, c \& d = $330 \mu \mathrm{m}$; $\mathrm{b}=150 \mu \mathrm{m} ; \mathrm{e}=33 \mu \mathrm{m} ; \mathrm{f}=270 \mu \mathrm{m}$.

testa with isodiametric cells with reticulate thickened outer walls (compare Plate 2b, I. siamensis T. Shimizu). The seedling belongs to 'subgroup E' (Shimizu, 1982). Group III, I. siamensis (Plate 2b), is characterized by a four-carpellate ovary and connate winged petals like Group II and III of section Microcentron Warb. The chromosome numbers of I. violiflora Hook.f. are 2n = 10 and 12 (Larsen, 1981) and that of I. santisukii T. Shimizu is $2 \mathrm{n}=10$ (Shimizu, unpubl.). 


\section{Section Microcentron Warb.}

This section can be divided into six groups of species. Group I, I. balsamina L. is characterized by a verrucose seed coat (Plate 2c) and inflated tomentose capsules. These capsules are very characteristic and not seen in any of the other groups. The seedling type of this species belongs to 'subgroup C' (Shimizu, 1982). Its chromosome number is variable, $2 \mathrm{n}=12,14,18,20,24$ and $14+2$ (Khoshoo, 1955, 1956, 1957; Chatterjee \& Sharma, 1970). Group II is characterized by testa cells with reticulate thickened outer walls. This group includes I. arriensii (Zoll.) T. Shimizu, I. bunnackii T. Shimizu, I. charanii T. Shimizu, I. harmandii Hook.f. (Plate 2d), I. kanburiensis T. Shimizu, I. macrosepala Hook.f., I. obesa Hook.f. and I. saraburiensis T. Shimizu. Group III, including I. hongsonensis T. Shimizu, I. kerriae Craib, I. parishii Hook.f. and I. psittacina Hook.f. (Plate 2e), is characterized by a finely granulate seed coat. These species are very unique in having a glabrous, four-carpellate ovary. The species mentioned above, together with some others, should be treated as a third subgenus of Impatiens. This group is restricted to South Asia, from South China to South Indonesia. Group IV, represented by I. boni Hook.f., I. cardiophylla Hook.f. and I. namkatensis T. Shimizu (Plate 2f), is characterized by a 'warted' epidermis. These 'warts' appear to be glands derived from a single epidermal cell and are distributed over the entire surface of the testa. These species have four carpellate ovaries and connate winged petals. Like Group III, Group IV should be transferred to a new subgenus. Impatiens siamensis of section Macrocentron probably belongs to the same new subgenus. Group $\mathrm{V}$ is heterogeneous in floral characters: I. salaengensis T. Shimizu has a four-carpellate ovary, while I. tripetala Roxb. has a five-carpellate ovary. In this case, seed characters are considered as homoplastic. Group VI, I. muscicola Craib, should be regarded as a member of section Macrocentron on the basis of flower morphology and seedling type.

\section{Section Megalocentron Warb.}

This section is characterized by alternate leaves, racemes with 2-5 flowers with long spurred lips. This section can be divided into two groups. Group I is characterized by a testa with papillae (Plate 3a, I. garrettii Craib). Impatiens garrettii has violet and red striped flowers with curved spurs. Impatiens tapanuliensis Grey-Wilson has yellow flowers with stripes and straight spurs. No features common to these species were found. Group II is represented by rheophytic plants with flabellate wing petals.

\section{Section Brachycentron Warb.}

This section is divided into two groups. Group I is characterized by a reticulate seed coat as seen in I. hypophylla Makino, I. textori Miq. (Plate 3b) and I. noli-tangere L. (Plate 3c). The seedlings of I. noli-tangere and I. textori belong to 'subgroup C' (Shimizu, 1982). Group II, I. alboflava Miq. and I. larsenii T. Shimizu, is characterized by a seed coat with two kinds of granules: large and small (Plate 3d, e). These two species are peculiar in having non-pendulous flowers and asymmetric wing petals (Utami \& Shimizu, 1998). Warburg \& Reiche (1895) classified I. alboflava as a member of sect. Brachycentron together with I. noli-tangere and I. textori. However, the seed coat features indicate that I. alboflava and I. larsenii may better be placed in sect. Microcentron. 

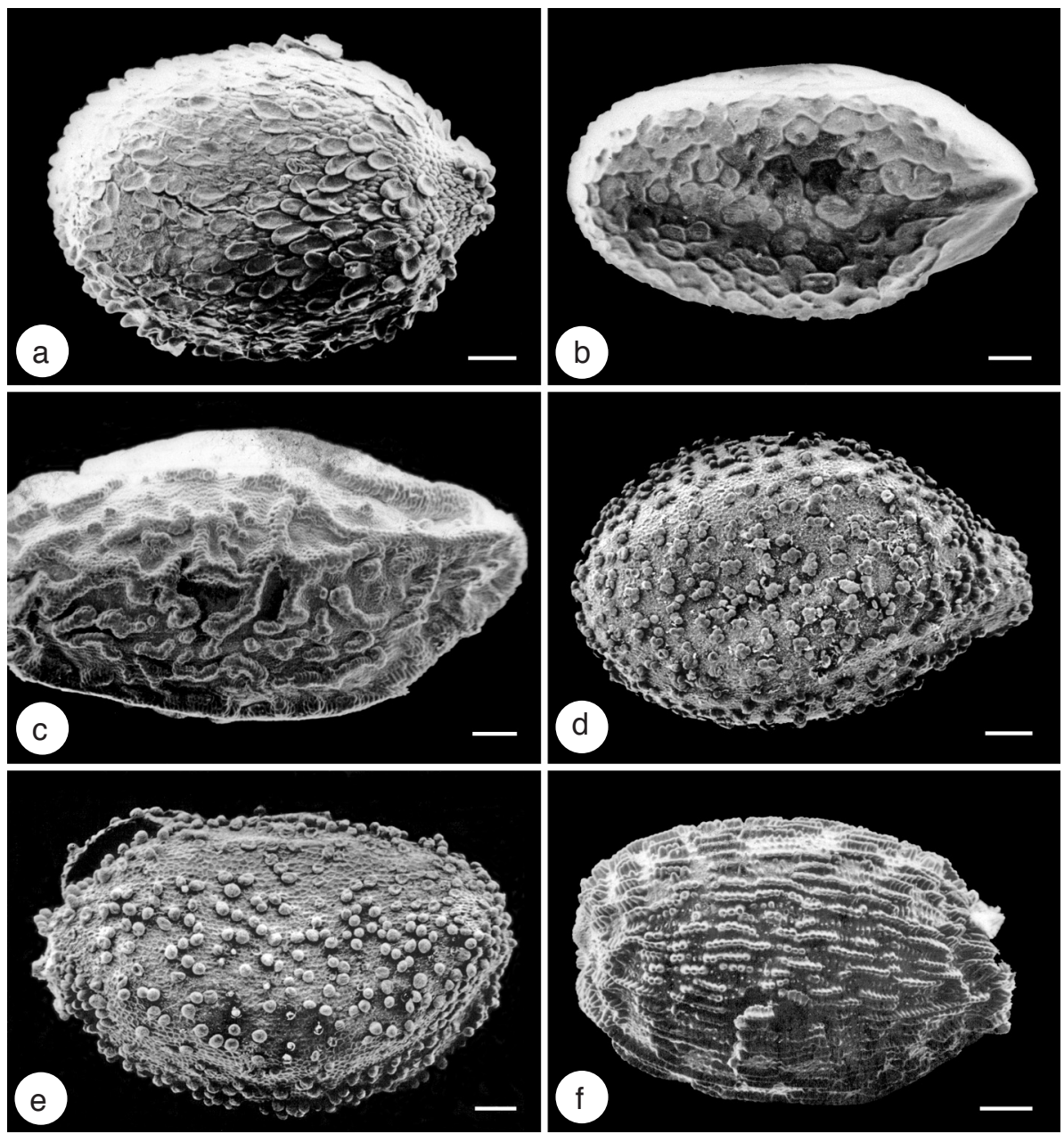

Plate 3. SEM-photographs of seeds of Impatiens species. - a. Sect. Megalocentron Warb.: I. garrettii Craib: testa with papillae. - b-e: Sect. Brachycentron Warb.: b. I. textori Miq.: testa with a reticulate pattern; c. I. noli-tangere L.: testa cells with reticulate thickened outer walls; d. I. alboflava Miq.: testa cells with granulate thickened outer walls; e. I. larsenii T. Shimizu: testa cells with granulate thickened outer walls. - f. Sect. Longicornes Warb.: I. cordata Wight with longitudinally arranged testa cells. - Scale bars: $\mathrm{a}-\mathrm{c}=330 \mu \mathrm{m} ; \mathrm{d}=260 \mu \mathrm{m} ; \mathrm{e}=210 \mu \mathrm{m} ; \mathrm{f}=310 \mu \mathrm{m}$.

\section{Section Longicornes Warb.}

This section is characterized by alternate leaves, many-flowered umbels and flowers with a long spur. Impatiens cordata Wight of India and I. walleriana Hook.f. ex Oliv. of Africa belong to this section. These two species differ greatly in their seed coat structure: I. cordata (Plate 3f) is peculiar in having ciliate seeds, while I. walleriana (Plate 4a) has a pattern similar to that of sect. Macrocentron, Group I. However, the chromosome number of $I$. walleriana is $2 \mathrm{n}=16$ (Arisumi, 1980), while Group I of sect. Macrocentron has $2 \mathrm{n}=10$ or 12 . 


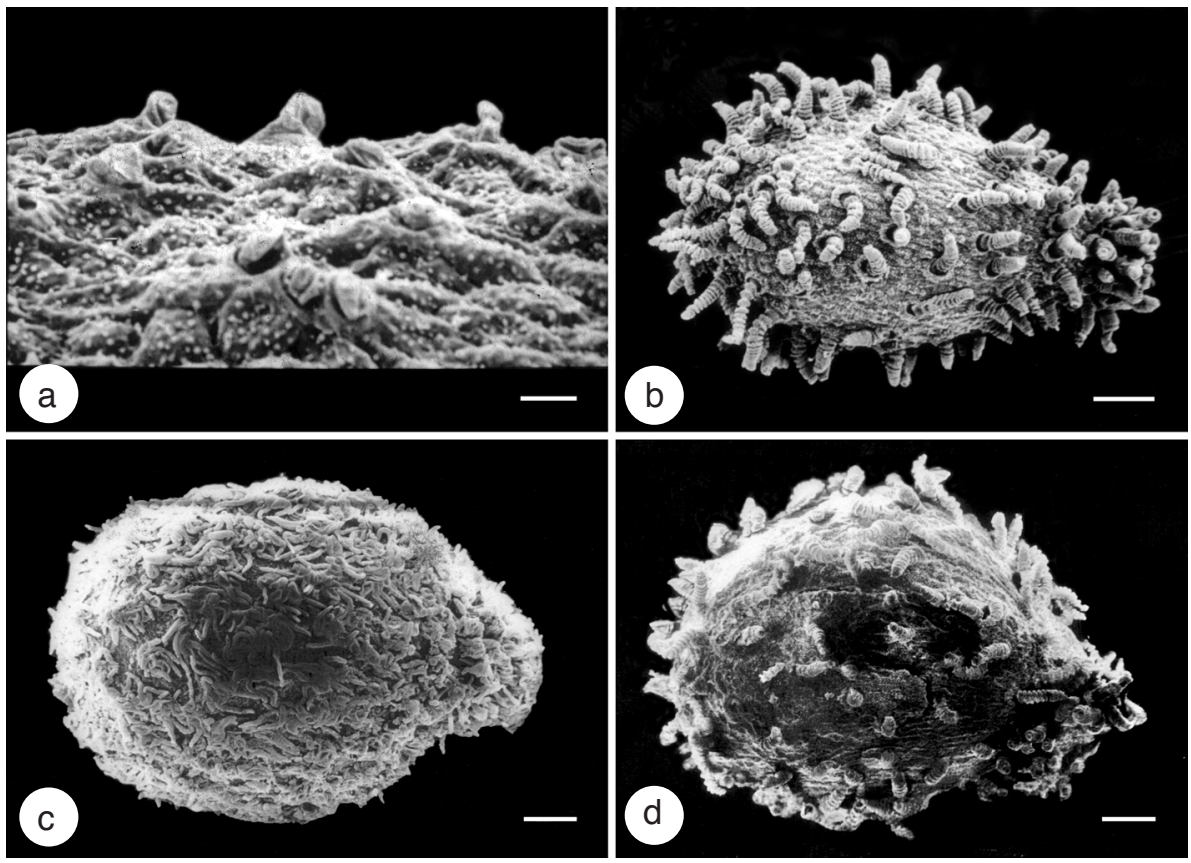

Plate 4. SEM-photographs of seeds of Impatiens species. - a. Sect. Longicornes Warb.: I. walleriana Hook.f. ex Oliv.: outer walls of the testa cells nipple-shaped. - b \& c: Sect. Salpingochillon Warb.: b. I. goughii Wight: testa cells with reticulate thickened outer walls; c. I. benthami Steenis with 'long hairs' around the testa. - d. Sect. Choniochillon Warb.: I. omissa Hook.f.: testa cells with reticulate thickened outer walls. - Scale bars: $\mathrm{a}=34 \mu \mathrm{m} ; \mathrm{b} \& \mathrm{~d}=170 \mu \mathrm{m} ; \mathrm{c}=250 \mu \mathrm{m}$.

\section{Section Salpingochillon Warb.}

Impatiens goughii Wight (Plate 4b) and I. benthami Steenis (Plate 4c) of India are characterized by opposite leaves and inflorescences with few flowers with a short spur. These two species have a seed coat similar to that of several species of sections Enantiophyllon (Group II), Megalocentron (Group III) and Choniochillon Warb.

\section{Section Choniochillon Warb.}

This section is characterized by opposite leaves and inflorescences with many flowers with a long spur. The two species of this section I. omissa Hook.f. (Plate 4d) and I. viscosa Bedd. of India, have the same type of seed coat as section Enantiophyllon (Group II), Megalocentron (Group III) and Salpingochillon. The chromosome numbers of these two species are $2 \mathrm{n}=28$ for I. omissa and $2 \mathrm{n}=16$ for I. viscosa (Rao, 1972).

\section{CONCLUSION}

The genus Impatiens has a most diverse and elaborately sculptured seed coat. The seed coat patterns can be used for distinguishing groups or aggregates. However, seed coat morphology alone does not provide universally applicable key characters for identification, but it can be as helpful as many other characters used in taxonomy. These 
seed coat types were sometimes well concordant with the classical classification of the genus but sometimes not. Especially in the South-East Asian species, the seed coat characters agrees well with other morphological characters to form natural groups.

As a result of the morphological and seed coat morphological examinations carried out, it is concluded that a number of good species groups should be recognized in Impatiens as more natural. Several species in sect. Microcentron which are characterized by four carpellate ovaries, connate winged petals and seed coat pilose with long hairs or granulate and finely granular form a new subgenus in Impatiens that will be published in a separate paper.

\section{REFERENCES}

Arisumi, T. 1980. Chromosome numbers and comparative breeding behavior of certain Impatiens from Africa, India and New Guinea. J. Am. Soc. Hort. Sci. 105: 99-102.

Barthlott, W. 1990. Scanning electron microscopy of the epidermal surface in plants. In: D. Claugher (ed.), Scanning Electron Microscopy in taxonomy and functional morphology. Syst. Assoc. Special Vol. 41.

Bhaskar, V. \& B.A. Razi. 1972. Studies in South Indian Balsaminaceae I. J. Mysore Univ. Sect. B. 25: $115-122$.

Bhaskar, V. \& B.A. Razi. 1974. New chromosome counts in South Indian Impatiens L. (Balsaminaceae). Proc. Ind. Sci. Congr. Assoc. 61 (IIIB): 35.

Bhaskar, V. \& B.A. Razi. 1978. Studies of South Indian Impatiens L. III. Further notes. Indian J. Bot. 1: 68-78.

Boesewinkel, F.D. \& F. Bouman. 1984. The seed: structure. In: B.M. Johri (ed.), Embryology of Angiosperms: 567-610. Springer-Verlag, Berlin, Heidelberg, New York, Tokyo.

Brisson, J.D. \& R.L. Peterson. 1976. A critical review of the use of the scanning electron microscopy in the study of seed coat. Scanning Electron Microsc. 2: 477-495.

Chatterjee, A. \& A.K. Sharma. 1970. Chromosome study in Geraniales. The Nucleus 13: 179-200.

Corner, E.J.H. 1976. The seeds of Dicotyledons I. Cambridge University Press, London.

Grey-Wilson, C. 1980. Impatiens of Africa. Balkema, Rotterdam.

Hooker, J.D. \& T. Thomson. 1859. Precursores ad floram indicam: Balsamineae. J. Linn. Soc. 4: $106-157$.

Khoshoo, T.N. 1955. Cytology of Impatiens. Current Sci. 24: 423-424.

Khoshoo, T.N. 1956. Chromosomes from herbarium sheets of Impatiens. Stain Technol. 31: 31-33.

Khoshoo, T. N. 1957. Cytology of some Impatiens species. Caryologia 10: 55-72.

Kumar, P. \& D. Singh. 1990. Development and structure of seed coat in Hibiscus. Phytomorph. 40: $179-188$.

Larsen, K. 1981. Chromosome numbers in Impatiens from Thailand. Nord. J. Bot. 1: 1-123.

Rao, R.V.S. 1972. Cytological studies in the South Indian Balsaminaceae. Proc. Indian Sci. Congr. 60: 137.

Shimizu, T. 1982. Seedling morphology in some Thai Impatiens and its taxonomic significance. J. Fac. Lib. Arts, Shinsu Univ., Nat. Sci. 16: 85-97.

Shimizu, T., S. Takao \& A. Takao. 1990. Triasporangiate anthers found in the genus Impatiens (Balsaminaceae). Bot. Mag. Tokyo 103: 335-337.

Utami, N. \& T. Shimizu. 1998. A taxonomical study of Impatiens alboflava Miq. (Balsaminaceae) from Sumatra. Jour. Biol. Ind. II: 2: 95-103.

Warburg, O. \& K. Reiche 1895. Balsaminaceae. In : A. Engler \& K. Prantl (eds.), Die natürlichen Pflanzenfamilien 3, 5: 390-392. Engelmann, Leipzig.

Wunderlich, R. 1967. Some remarks on the taxonomic significance of the seed coat. Phytomorphology $17: 301-311$.

Zinov'Eva-Stahevitch, A.E. 1981. Chromosome numbers in Impatiens (Balsaminaceae). PhD thesis. McGill University Toronto, Canada (unpublished). 